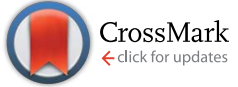

Cite this: RSC Adv., 2017, 7, 15342

Received 5th October 2016

Accepted 21st February 2017

DOI: 10.1039/c6ra24760a

rsc.li/rsc-advances

\section{Polyaniline nanoflowers grafted onto nanodiamonds via a soft template-guided secondary nucleation process for high- performance glucose sensing $\dagger$}

\begin{abstract}
S. Komathi, $\star^{a}$ A. I. Gopalan, $t^{b c}$ N. Muthuchamy and K. P. Lee ${ }^{\star b c}$
Superfine polyaniline (PANI) nanoflowers (NF) with protruded whiskers at the edge of the flowers were produced on the surface of nanodiamonds (NDs) using cetyltrimethylammonium bromide (CTAB) as a soft template and fine tuning the graft co-polymerization conditions. Typically, the amount of aminofunctionalized ND $\left(\mathrm{ND}-\mathrm{NH}_{2}\right)$ and the soft template CTAB used in the graft polymerization plays an important role in directing the NF morphology. The correlation between the amount of ND- $\mathrm{NH}_{2}$ and morphology has been discussed in terms of secondary nucleation for PANI growth. More importantly, the ND-grafted PANI (ND $-g$-PANI) NF exhibits a superior performance for glucose detection and possesses wider linear concentration range (1-30 mM), low detection limit $(0.018 \mathrm{mM})$, and high

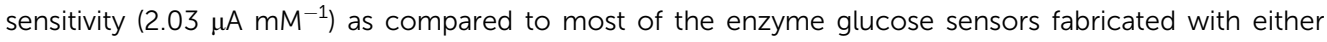
PANI or carbon nanostructures. The results obtained from this study offer scope for future studies on the fabrication of new biosensors with other aniline derivatives and carbon nanostructures.
\end{abstract}

\section{Introduction}

Glucose is a universal nutrient that performs fundamental roles in energy supply, carbon storage, biosynthesis, and cell wall formation. Diabetes mellitus is a common metabolic disorder and the control of blood glucose is highly necessary to reduce the diabetes-related complications such as cardiovascular disease, chronic renal failure, nerve damage, and blindness., ${ }^{\mathbf{1 , 2}}$ For the last 30 years, intensive studies have been conducted on the use of enzymes for bioelectrocatalysis towards the development of biosensors, bioreactors, and biofuel cells. ${ }^{3-5}$ Traditionally, enzymes are used to detect glucose via a process involving the reduction of the enzyme and simultaneous oxidation of the glucose molecules. However, there are few issues related to the electrochemistry of enzymes at bare electrodes; for example, enzymes have a short lifetime and lose their activity at bare electrodes. ${ }^{6}$ Moreover, there are electron transport issues associated with the long paths between the sites of a biocatalyst (enzyme) and the electrode. Thus, enzyme-based glucose sensors suffer from insufficient long-term stability,

a Deparment of Chemistry Education, Kyungpook National University, Daegu, S. Korea ${ }^{b}$ Research Institute of Advanced Energy Technology, Kyungpook National University, Daegu, S. Korea. E-mail: kplee@knu.ac.kr

${ }^{c}$ Department of Nanoscience and Nanotechnology, Kyungpook National University, Daegu, S. Korea

$\dagger$ Electronic supplementary information (ESI) available. See DOI: 10.1039/c6ra24760a

\$ Authors contributed equally to this work. low sensitivity, and particularly complicated enzyme immobilization procedures. To resolve these problems, studies have been focused on the immobilization of enzymes at the electrode surface using different strategies. ${ }^{7,8}$ The strategies of enzyme immobilization on the electrodes include covalent binding of enzymes or wiring of enzymes to the electrode using a linker, ${ }^{9}$ sandwiching the enzymes between two layers of polymers, ${ }^{10}$ employing multicomponents to maintain enzyme activity, ${ }^{\mathbf{1 1}}$ and entrapment in a polymer membrane/network. ${ }^{12}$ Covalent binding decreases the enzyme activity and sandwiching techniques result in non-uniform distribution of the enzyme. Among the various approaches for enzyme entrapment, the use of conductive polymers (CPs) is attractive. ${ }^{\mathbf{1 3 - 1 5}}$ In the fabrication of biosensors, polyaniline (PANI) serves as a perfect matrix for the immobilization of enzymes ${ }^{\mathbf{1 6}, \mathbf{1 7}}$ and functions as a mediator to improve the signal application. ${ }^{\mathbf{1 8 , 1 9}}$ The combination of carbon nanomaterials and PANI has been reported to be efficient in improving the sensitivity, selectivity, and stability of enzyme-based sensors. ${ }^{\mathbf{2 0 , 2 1}}$ Carbon nanotube (CNT)/PANI nanocomposites exhibit improved catalytic properties for biomolecules such as hydrogen peroxide, oxygen, glucose, and ascorbic acid. ${ }^{22-25}$

Diamond has emerged as an electrode material because of its excellent electrochemical properties such as wide potential window, ${ }^{26,27}$ electrochemical stability, resistance to electrode fouling, ${ }^{28}$ and insensitivity to oxygen dissolution in aqueous solution. ${ }^{29}$ Diamond electrodes can be even used for the electrolysis of molecules with a high oxidation potential ${ }^{30}$ both in aqueous and non-aqueous media. ${ }^{31}$ Nanodiamond (ND) powder 
has found various applications such as intracellular imaging, drug delivery, biosensors, and biochips because of its biocompatibility, chemical inertness, chemical stability, wide potential window, and optical transparency. ${ }^{32,33}$ Moreover, undoped ND is an insulating material. The conductivity of ND can be improved by the introduction of impurities such as boron, nitrogen, phosphorous, and sulfur. ${ }^{34}$ These impurities may accumulate in the intercrystalline regions and promote $\mathrm{sp}^{2}$ carbon bonding in grain boundaries. ${ }^{35}$ However, doping is not a unique approach to make diamond conducting.

Surface modifications of ND have been facilitated due to the high surface area availability of unsaturated surface atoms. Surface modification of ND can induce a good dispersion of NDs in solvents and can modify its properties such as conductivity and electroactivity. Covalent surface modifications of diamond particles are generally used in the process of improving the properties of NDs as well to introduce functional groups. The functionalized surfaces of diamond are excellent for the selfassembly of proteins. Garrido et al. ${ }^{36}$ reported the modification of the surface layer of ND with amino groups for protein immobilization. A glucose sensor based on the covalent immobilization of glucose oxidase onto the surface of ND has been reported. ${ }^{37}$ Multilayer films of ND and hemoglobin were constructed via the layer by layer method, and the direct electron transfer was investigated. ${ }^{38}$ The immobilization of antibodies onto silica-functionalized ND and its efficiency towards bacterial binding were investigated. ${ }^{39}$ The use of polymer coatings on nanoparticles is very attractive. Li et al. ${ }^{40}$ reported the preparation of a diamond-polymer nanocomposite by grafting chains of poly(methyl methacrylate) through the atom transfer radical polymerization process. Polyethyleneimine-functionalized ND platforms (via covalent conjugation) were used as vehicles for gene delivery. ${ }^{\mathbf{4 1}}$ Actis et $a .^{\mathbf{4 2}}$ reported the covalent linking of pyrrole units onto the boron-doped diamond surface through electropolymerization. The electrical conductivity of diamond was improved by polymerizing a layer of PANI on undoped ND. ${ }^{52}$ The results indicated that the resistance of the diamond electrode is greatly reduced after the deposition of PANI. However, note that the diamond/PANI composite reported in the earlier study ${ }^{43}$ consisted of a layer of PANI over diamond and the PANI chains were not chemically linked to the diamond surface. This bilayer configuration is not suited for sensor applications. Nanostructured conduction polymers (NCPs) have been widely utilized for chemical/biological sensors. ${ }^{\mathbf{4 4 , 4 5}}$ Among the different types of NCPs, the topological features of nanoflowers (NF) have attracted the interest of scientists because of their high surfaceto-volume ratio, which is beneficial for the enhancement of surface-based reactions. However, to date, no study has been reported on the utilization of flowers, such as CPs grafted on the ND backbone, towards enzyme immobilization and biosensor fabrication.

Herein, we report the preparation of ND-grafted PANI NF $\left(\mathrm{ND}_{x}-\mathrm{g}\right.$-PANI) NF through a soft template approach and their utilization towards the amperometric determination of glucose. The preparation conditions of $\mathrm{ND}_{x}$ - $g$-PANI were optimized to obtain the desired NF morphology. Field emission scanning microscopy illustrates the formation of PANI NF on ND under the optimized conditions. The physicochemical characteristics of $\mathrm{ND}_{x}$ - $g$-PANI-NF were evaluated through UV-visible spectroscopy, thermogravimetric analysis, and X-ray photoelectron spectroscopy. To the best of our knowledge, this is the first time that this $\mathrm{ND}_{x}-\mathrm{g}$-PANI-NF electrode has been used for the sensitive electrochemical detection of glucose. The fabricated sensor exhibits excellent selectivity, fast response, wide linear range, and good reproducibility for glucose detection.

\section{Materials and methods}

\subsection{Chemicals}

Synthetic diamond (K. Diamond; USA) with an average size of $130 \mathrm{~nm}$, which was supplied as a gift sample, was washed with a mixture of $9: 1(\mathrm{v} / \mathrm{v})$ concentrated $\mathrm{H}_{2} \mathrm{SO}_{4}$ and $\mathrm{HNO}_{3}{ }^{46}$ The characterization details of the supplied ND have been reported elsewhere. ${ }^{\mathbf{4 6 , 4 7}}$ The reproducibility of the ND sample towards sensor applications has been demonstrated earlier. ${ }^{\mathbf{4 8} 49}$ Aniline, ammonium persulfate (APS), and polyethylene glycol diamine (PEGDA) were obtained from Sigma-Aldrich, S. Korea. Human serum (from human male A plasma, USA origin, sterile-filtered) was obtained from Sigma-Aldrich, S. Korea. Cetyltrimethylammonium bromide (CTAB) was obtained from TCI (S. Korea). Reagent grade glucose oxidase (GOx) (E.C 1.1.3.4, $151 \mathrm{U} \mathrm{mg}^{-1}$, from Aspergillus niger; U: enzyme units) and glutaraldehyde were purchased from Sigma-Aldrich, Inc., USA. Double-distilled water (resistivity $=\sim 19 \mathrm{M} \Omega \mathrm{cm}$ ) was used throughout the experiments. Aqueous solutions of analytes were prepared in $0.1 \mathrm{M}$ phosphate buffer saline (PBS; pH 7) fresh at the time of experiments. Indium tin oxide (ITO)-coated glass (specific resistance of $15 \Omega$, Corning Inc., USA) was first degreased with acetone and then washed in distilled water before use.

\subsection{Preparation of $\mathrm{ND}_{x}-g$-PANI-NF}

Two major stages were involved in the preparation of $\mathrm{ND}_{x}-g$ PANI-NF: (i) amine $\left(-\mathrm{NH}_{2}\right)$ functionalization of ND to give ND$\mathrm{NH}_{2}$ and (ii) surfactant (CTAP)-assisted graft polymerization of amine onto the $\mathrm{ND}-\mathrm{NH}_{2}$ surface. $\mathrm{ND}-\mathrm{NH}_{2}$ was prepared based on a similar procedure reported for the $-\mathrm{NH}_{2}$ functionalization of multi-walled carbon tubes. ${ }^{23,25}$ The calculated amount of ND$\mathrm{NH}_{2}(x)(1,5$, and $10 \mathrm{mg})$ was dispersed in $42.7 \mathrm{~mL}$ of $1.0 \mathrm{M} \mathrm{HCl}$ containing $0.05 \mathrm{M}$ CTAB and subjected to ultrasonication (BRANSON digital sonifier) for $1 \mathrm{~h}$ to obtain a homogeneous dispersion. To the $\mathrm{ND}^{-\mathrm{NH}_{2}}$ dispersion, $2.30 \mathrm{~mL}$ of aniline was added to achieve a concentration of $0.05 \mathrm{M}$ aniline in the reaction system and stirred for $30 \mathrm{~min}$. To the homogeneous dispersion, a precooled $5.0 \mathrm{~mL}$ solution of $0.25 \mathrm{M}$ of APS was added dropwise and stirred for $6 \mathrm{~h}$ to obtain a green precipitate. The precipitate was dried at $60{ }^{\circ} \mathrm{C}$ for $6 \mathrm{~h}$ and stored in a refrigerator at $4{ }^{\circ} \mathrm{C}$ for $24 \mathrm{~h}$. The product was identified as $\mathrm{ND}_{x}$ $g$-PANI, where $x$ denotes the amount of $\mathrm{ND}-\mathrm{NH}_{2}$ used in the polymerization process. For comparative purposes, a pristine PANI sample was prepared by maintaining similar experimental conditions as used for the preparation of $\mathrm{ND}_{x}-\mathrm{g}$-PANI but in the absence of $\mathrm{ND}-\mathrm{NH}_{2}$. Typically, $2.3 \mathrm{~mL}$ of aniline was added to $42.7 \mathrm{~mL}$ of homogeneous dispersion of CTAB $(0.05 \mathrm{M})$ in $1.0 \mathrm{M}$ 
$\mathrm{HCl}$. Subsequently, $5.0 \mathrm{~mL}$ of $0.25 \mathrm{M}$ aqueous APS in $1.0 \mathrm{M} \mathrm{HCl}$ was added dropwise and stirred for $6 \mathrm{~h}$. The precipitate (pristine PANI) was collected and dried at $60{ }^{\circ} \mathrm{C}$ for $6 \mathrm{~h}$.

2.2.1. Fabrication of $\mathrm{ND}_{\boldsymbol{x}}$ - $\boldsymbol{g}$-PANI/GOx electrode. Precleaned ITO was used for the fabrication of a glucose sensor electrode. Typically, about $20 \mathrm{mg}$ of $\mathrm{ND}_{x}$-g-PANI was dispersed in a solution containing about $0.8 \mathrm{~mL}$ of water and $0.2 \mathrm{~mL}$ of Nafion solution in $5 \%$ ethanol and sonicated using a digital sonifier for $10 \mathrm{~min}$ to form a colloidal paste. About $50 \mu \mathrm{L}$ of paste was applied onto the surface of the ITO $\left(\right.$ area $\left.=1 \mathrm{~cm}^{2}\right)$ and dried in a vacuum oven at $25{ }^{\circ} \mathrm{C}$ for $8 \mathrm{~h}$. A solution of GOx $\left(10 \mathrm{mg} \cdot \mathrm{mL}^{-1}\right.$ ) in $0.1 \mathrm{M}$ PBS was prepared and stored at $4{ }^{\circ} \mathrm{C}$. About $5 \mu \mathrm{L}$ glutaraldehyde was added over the $\mathrm{ND}_{x}$-g-PANI layer coated on the ITO electrode and on top of that $20 \mu \mathrm{L}$ GOx in $0.1 \mathrm{M}$ PBS was added and allowed to dry at room temperature $\left(25{ }^{\circ} \mathrm{C}\right)$. The $\mathrm{ND}_{x}-g$-PANI/GOx electrode was preserved in a refrigerator at $4{ }^{\circ} \mathrm{C}$ after being washed with a $0.1 \mathrm{M}$ PBS solution.

\subsection{Instrumentation}

The morphology of $\mathrm{ND}_{x}-g$-PANI was examined via scanning electron microscopy (FESEM) (Hitachi, S-4200, Japan). Samples were mounted on the microscope and sputtered with a thin layer of platinum particles before viewing. FESEM images were obtained at the accelerating voltage of $15 \mathrm{kV}$. The oxidation states of PANI were evaluated by X-ray photoelectron spectroscopy (XPS) (ULVAC-PHI model Quantera SXM). A Fourier transform infrared spectrometer (FTIR) (Jasco, IR-610, USA) was used to obtain the spectra of the polymers and composites using $\mathrm{KBr}$ pellets. The thermal stability (TG-DTA) (Seiko, TMA 120 , Japan) of the samples was determined at the heating rate of $10{ }^{\circ} \mathrm{C} \min ^{-1}$ under a nitrogen atmosphere over the temperature range of $30-800{ }^{\circ} \mathrm{C}$. Ultraviolet-visible optical absorption spectra (Shimadzu, UV-2101, Japan) of the samples were obtained using quartz cuvettes $(1 \mathrm{~cm})$ at room temperature in the range of 200-800 $\mathrm{nm}$. Chronoamperometry was performed via IVIUMSTAT and COMPACTSTAT (The Netherlands) instruments using the three-electrode cell set-up comprising Pt wire (auxiliary), $\mathrm{Ag} / \mathrm{AgCl}_{\mathrm{satKCl}}$ (reference), and modified indiumdoped tin oxide-coated glass plate (ITO) or glassy carbon (GC) (working) electrodes. The chronoamperometric response of $\mathrm{ND}_{x^{-}} g$-PANI/GOx towards glucose was studied at the applied potential of $+0.4 \mathrm{~V}$ under stirring. The current response was obtained as follows. After applying the potential $(+0.4 \mathrm{~V})$, the current was allowed to reach a stable value and small aliquots of glucose solutions were added at regular intervals, and then the response was obtained. The stock solution of glucose was prepared in $0.1 \mathrm{M}$ PBS. The selectivity of $\mathrm{ND}_{x}-g$-PANI/GOx towards glucose was tested by performing experiments in the presence of generally known interfering substances. ${ }^{\mathbf{5 0}}$

\section{Results and discussion}

\subsection{Morphology}

We optimized the conditions for $\mathrm{ND}_{x}$-g-PANI NF formation using different $x$ values during graft polymerization and subsequently monitoring the morphology of the resultant product. Fig. 1 presents the FESEM images of various $\mathrm{ND}_{x}$-g-PANI materials obtained by changing $x$ from $1 \mathrm{mg}$ to $10 \mathrm{mg}$ during graft polymerization. On examining the images shown in Fig. 1a-c, it can be noticed that $x$ has a pronounced effect on the morphology of the resultant product. For comparison, the FESEM image of pristine PANI, prepared in the absence of $\mathrm{ND}-\mathrm{NH}_{2}$, is presented Fig. 1d. Pristine PANI has an irregular fiber-like morphology (Fig. 1d) with an average diameter and length of $\sim 40 \mathrm{~nm}$ and $\sim 500 \mathrm{~nm}$, respectively. The formation of PANI nanofibers during the CTAB-assisted polymerization of aniline has been documented earlier. ${ }^{51}$ The FESEM images in Fig. 1a-c show that the morphology varies from nanofibers to nanoplates to NF with an increase in $x$ during graft polymerization. Typically, $\mathrm{ND}_{10^{-}} g$-PANI exhibits a well-defined flower-like morphology with pronounced whiskers. In the case of $\mathrm{ND}_{1}-g$-PANI, a flattened fiber-like morphology is observed (Fig. 1a), which originates due to the secondary growth of PANI over the formed $\mathrm{ND}_{x}-g$-PANI in the initial stage. This is because PANI formation is nucleated on the surface of $\mathrm{ND}-\mathrm{NH}_{2}$ since the surface of $\mathrm{ND}-\mathrm{NH}_{2}$ acts as a heterogeneous nucleation site. Thus, the introduction of $\mathrm{ND}-\mathrm{NH}_{2}$ into the mixture of $1 \mathrm{M} \mathrm{HCl} / 0.05 \mathrm{M} \mathrm{CTAB}$ solution prior to the polymerization of aniline induces the secondary growth of PANI and results in different morphologies as compared to that of the nanofibers of pristine PANI (Fig. 1d). The FESEM image of $\mathrm{ND}_{5}-g$ PANI (Fig. 1b) reveals the presence of extensively interlinked and flattened fibers or belts. Obviously, the increase in $-\mathrm{NH}_{2}$ sites on the ND surface causes an increase in secondary nucleation sites, which results in cross-linking between them. Thus, the formation of $\mathrm{NF}$ in the case of $\mathrm{ND}_{10^{-}} g$-PANI is ascribed to the extensive secondary nucleation and cross-linking reactions. When the number of $-\mathrm{NH}_{2}$ sites is higher, as in the case of $10 \mathrm{mg} \mathrm{ND}-\mathrm{NH}_{2}$, the $-\mathrm{NH}_{2}$ sites nucleate and are converted into short PANI chains, which subsequently transform into whiskers to result in a NF (Scheme 1). Previous reports suggest morphological variations by these secondary nucleation processes..$^{52-54}$

Herein, we proposed a plausible mechanism for the evolution of the NF morphology (Scheme 1C). First, the confined microenvironment derived from $\mathrm{ND}-\mathrm{NH}_{2}$ allows the nucleation, growth, and assembly of PANI on the surface of ND. When the number of nucleating sites increases (as in the case of $\mathrm{ND}_{1}$ - $g$ PANI), randomly oriented short fibers may be formed on the surface of ND (Fig. 1a, Scheme 1A). With a further increase in the number of $\mathrm{ND}-\mathrm{NH}_{2}$ sites, the short fibers generated at the individual sites of the ND surface subsequently assemble and generate flattened fibers (Fig. 1a, Scheme 1B) through intermolecular interaction between the fibers to result in petal-like structures. ${ }^{55}$ It has been earlier reported that the introduction of nanocomponents such as carbon nanotubes or metal nanoparticles or even nanofibers of PANI greatly influences the morphology of the final product. ${ }^{56}$ A rough surface of PANI was observed when pristine ND was mixed with PANI. ${ }^{57}$ Depending on the shape and size of CTAB aggregates in the reaction system, nanostructured PANI materials such as nanowires, ${ }^{\mathbf{5 8 , 5 9}}$ nanoparticles, ${ }^{60}$ and $\mathrm{NF}^{52,61}$ have been synthesized. In our study, we predicted the non-covalent functionalization of CTAB on the surface of ND-NH$\cdot{ }^{62,63}$ The CTAB molecules on the surface of 

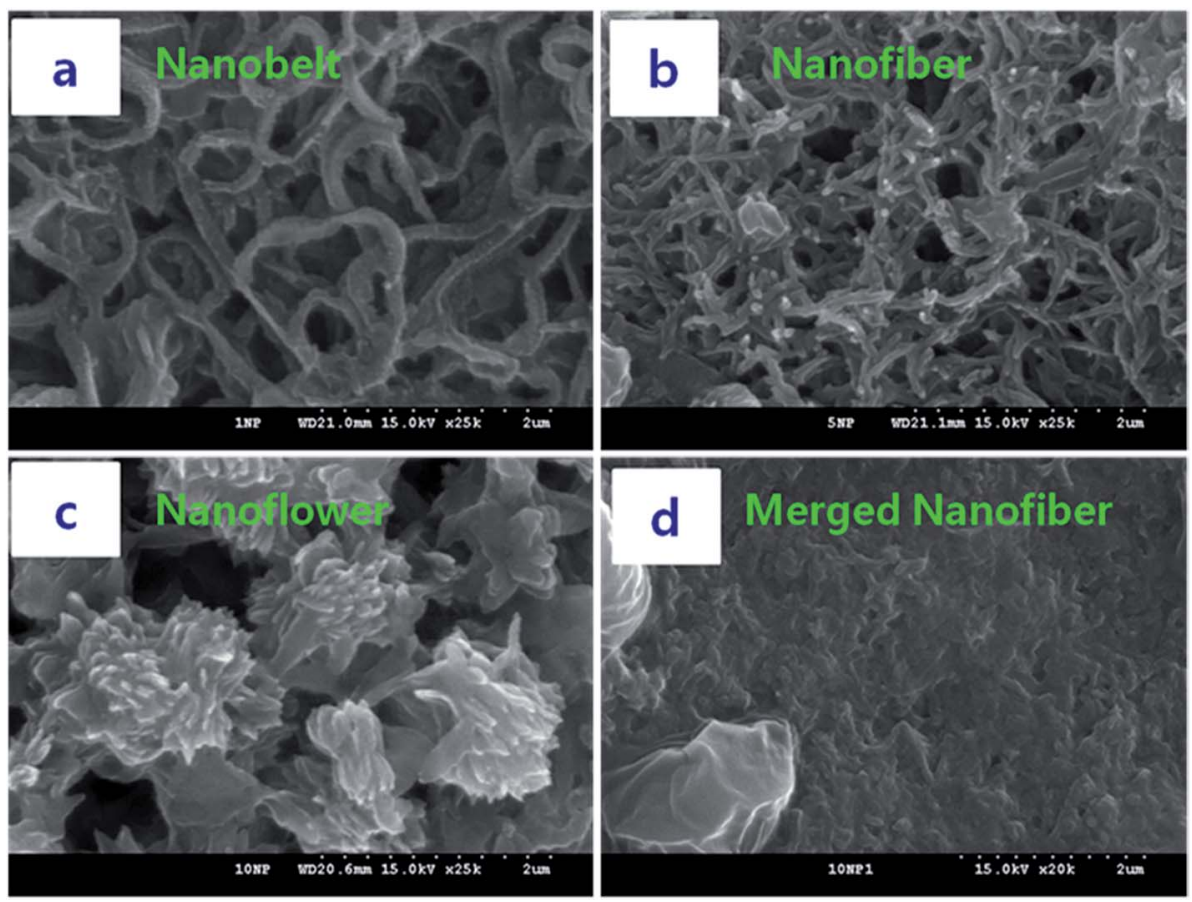

Fig. 1 FESEM images of (a) $\mathrm{ND}_{1}-g-\mathrm{PANI}$, (b) $\mathrm{ND}_{5}-g-\mathrm{PANI}$, (c) $\mathrm{ND}_{10}-g-\mathrm{PANI}$, and (d) PANI.

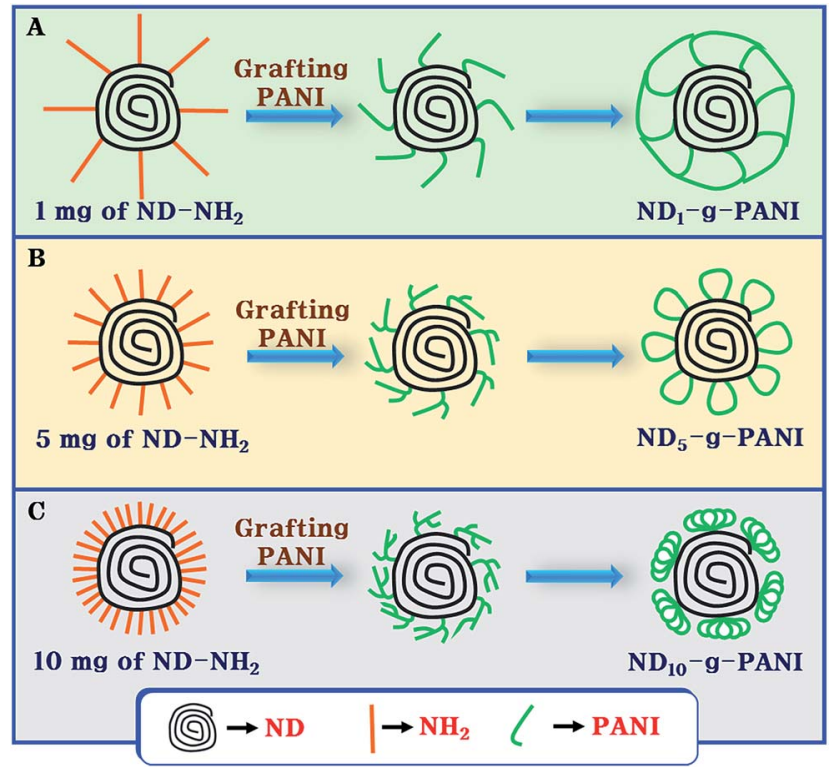

Scheme 1 Morphological evolution during $\mathrm{ND}_{x}-g$-PANI formation with different amounts of ND- $\mathrm{NH}_{2}(x): x=1.0 \mathrm{mg}(\mathrm{A}), 5.0 \mathrm{mg}(\mathrm{B})$, and $10.0 \mathrm{mg}(\mathrm{C})$ : (A) - nanofibers; (B) - nanoplates; and (C) - nanoflowers.

ND- $\mathrm{NH}_{2}$ generate different assemblies depending on $x$. Thus, CTAB acts as a soft template to provide channels for PANI chains to grow into fibers, belts, or NF.

\subsection{UV-visible spectroscopy}

The UV-visible spectra of $\mathrm{ND}_{x}-g$-PANI and pristine PANI obtained in NMP show three characteristic absorption bands (Fig. 2) around the wavelengths of $330 \mathrm{~nm}, 430 \mathrm{~nm}$, and
$>750 \mathrm{~nm}$. The presence of these three absorption bands indicate that the PANI chains in $\mathrm{ND}_{x}-g$-PANI are in the emeraldine salt (ES) form. ${ }^{64}$ The peak at $330 \mathrm{~nm}$ is attributed to the $\pi-\pi^{*}$ transitions in the benzenoid rings. The other two absorption bands at around 430 and $>750 \mathrm{~nm}$ are attributed to the polaron $\pi^{*}$ and $\pi$-polaron transitions, respectively. ${ }^{65}$ As reported in the literature, the UV-visible spectrum of PANI in NMP exhibits two characteristic absorptions, a broad band at around 630-650 nm (corresponding to the excitonic transitions of the organic aciddoped PANI chain) and a prominent peak at $320 \mathrm{~nm}$ (corresponding to the $\pi-\pi *$ transition) of the emeraldine base (EB) form of PANI. ${ }^{65}$ It has been reported that the PANI ES salt, which mostly has an organic acid dopant, in NMP converts into the PANI EB form, whereas the de-doping of the PANI chains is predominant. ${ }^{66,67}$ It is known that the doping-dedoping of PANI

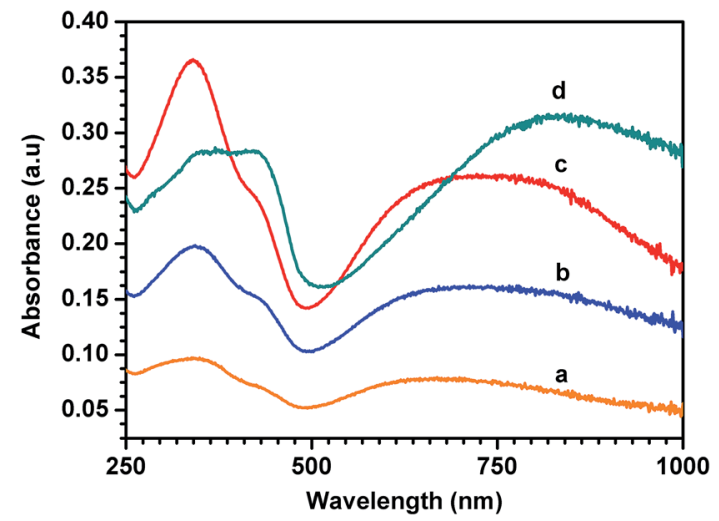

Fig. 2 UV-visible spectra of (a) $\mathrm{ND}_{1}-g$-PANI, (b) $\mathrm{ND}_{5}-g$-PANI, (c) $\mathrm{ND}_{10}-\mathrm{g}$-PANI, and (d) PANI. 
chains with organic/inorganic acids is an acid-base type reaction. NMP is a basic polar solvent and can interact with the protons $\left(\mathrm{H}^{+}\right)$of organic acids. Thus, in a solution of organic acid-doped PANI in NMP, there are two competitive reactions: (1) PANI + acid dopant $\rightarrow$ PANI-H ${ }^{+}$(doped PANI, PANI-ES) and (2) $\mathrm{NMP}+\mathrm{H}^{+}$(acid dopant) $\rightarrow \mathrm{NMP}-\mathrm{H}^{+}$(hydrogen bonding). Thus, under the conditions where reaction (2) is predominant, PANI is dedoped to PANI-EB. However, the dedoping of PANI chains in PANI-ES is not the predominant process in the cases where NMP-hydrogen bonding (reaction 2) is hindered by another competing process, which can result in the co-existence of doped and undoped states for PANI chains or the predominant existence of the doped state of PANI (PANI-ES). It has also been reported that the UV-visible spectrum of PANI nanostructures (prepared in the presence of CTAB) exhibits three

Table 1 Investigation of doping of $\mathrm{ND}_{x}-g$-PANI and PANI from the intensity ratio

\begin{tabular}{ll}
\hline Sample & Intensity ratio $^{a}$ \\
\hline PANI & 1.065 \\
$\mathrm{ND}_{1}-g$-PANI & 0.778 \\
$\mathrm{ND}_{5}-g$-PANI & 0.759 \\
$\mathrm{ND}_{10}-$-PANI & 0.718 \\
${ }^{a}$ At the wavelengths between $330 \mathrm{~nm}$ and $750 \mathrm{~nm}$. &
\end{tabular}

bands that are characteristics of PANI-ES. ${ }^{68}$ In this study, the three absorption bands that are characteristic of PANI-ES were observed in the UV-visible spectrum of $\mathrm{ND}_{x}-\mathrm{g}$-PANI, which is prepared from an aqueous $\mathrm{CTAB}-\mathrm{HCl}$ mixture. We attributed the following reason for the spectral features observed in this study. We employed a template (CTAB)-directed chemical oxidative polymerization for the synthesis of $\mathrm{ND}_{x}-g$-PANI and nanostructured pristine PANI. The surfactant CTAB, in addition to directing the morphology of the polymer, can also wrap-up the PANI chains through electrostatic interactions between the protonated ammonium sites of CTAB and $\mathrm{Cl}^{-}$ions in the doped PANI. ${ }^{69-71}$ As a consequence, the $\mathrm{Cl}^{-}$ions doped into the PANI chains are trapped within the PANI chains to result in PANI-ES. The ratio of the peak intensity at $\lambda_{330 \mathrm{~nm}}$ and $\lambda_{750 \mathrm{~nm}}$ is an indication of the level of PANI chains doping. ${ }^{72}$ It was observed that the doping was maximum for PANI and the value decreased with $x$ in $\mathrm{ND}_{x}$ - $g$-PANI (Table 1$)$. The physicochemical properties such as doping level and conjugation length are highly dependent on the morphologies such as nanofibers, nanowires, nanorods, and NF, of the conductive polymers. ${ }^{73,74}$ It has been reported that the doping level of PANI nanostructures follow the trend nanofibers $>$ nanorods $>$ nanoparticles. ${ }^{75}$ The fiber-like morphology of pristine PANI (Fig. 1d) could be the reason for the higher doping level (Table 1). The enhanced doping level and conjugation length for pristine PANI are
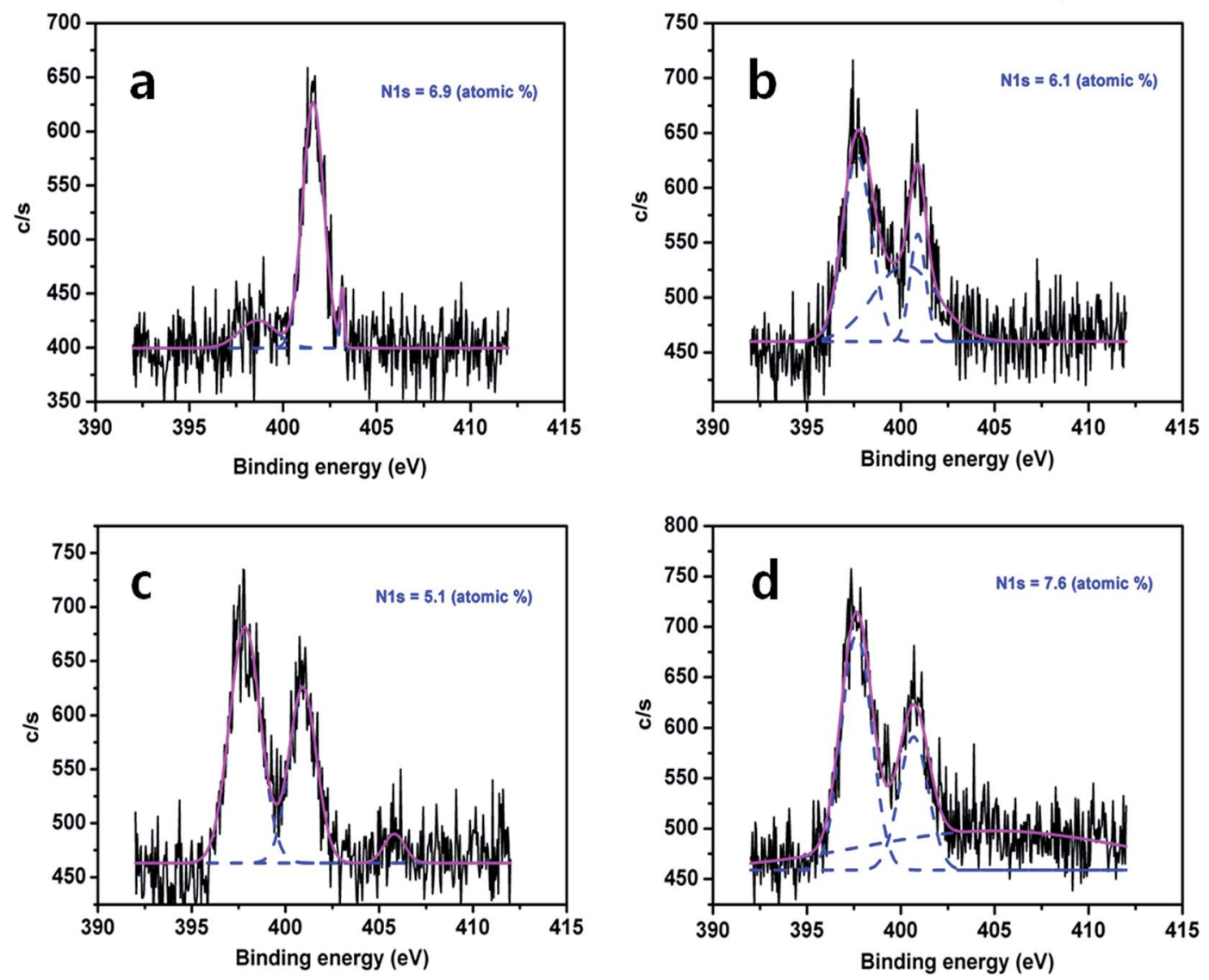

Fig. 3 XPS spectra of (a) $N_{1}-g-P A N I$, (b) $N D_{5}-g-P A N I$, (c) $N D_{10}-g-P A N I$, and (d) PANI. 
expected to originate from the high aspect ratio of nanofibers in pristine PANI (Fig. 1d) compared to that of platelet/NF morphologies for $\mathrm{ND}_{x}$-g-PANI (Fig. 1a-c).

\subsection{X-ray photoelectron spectroscopy}

The N1s core level spectra of $\mathrm{ND}_{x}-g$-PANI and pristine PANI were deconvoluted into Gaussian component peaks ${ }^{76,77}$ (Fig. 3). The core level N1s spectra were fitted into three main chemical states due to the different chemical environments possible for PANI. The chemical states were imine $(-\mathrm{NH}=)$, amine $(-\mathrm{NH}-)$, and protonated amine and imine (Table 2). ${ }^{78}$ The results revealed that the PANI chains in pristine PANI and $\mathrm{ND}_{x}-g$-PANI existed in the emeraldine form containing both benzenoid amine $(-\mathrm{NH})$ and quinoid amine $(=\mathrm{N}-)$ units. However, there are differences in the doping level of PANI chains (the contribution of $-\mathrm{N}^{+}$species to the total nitrogen content) between PANI and $\mathrm{ND}_{x}-g$-PANI. Pristine PANI is highly doped with the doping level of $48 \%$. On the contrary, the doping level of PANI is much lower in $\mathrm{ND}_{x}-\mathrm{g}$-PANI. This suggests that the inclusion of ND into the PANI chains decreases the doping level.

\subsection{Fourier transform infrared spectroscopy}

Fig. 4 shows the FTIR spectra of the pristine PANI and $\mathrm{ND}_{x}{ }^{-g}$ PANI samples prepared with different amounts of ND. The bands at around $1600 \mathrm{~cm}^{-1}$ and $1500 \mathrm{~cm}^{-1}$ are attributed to the $\mathrm{C}=\mathrm{N}$ stretching mode and $\mathrm{C}=\mathrm{C}$ stretching vibration of quinoid (Q) and benzenoid (B), respectively. The peaks were assigned based on earlier literature. ${ }^{79-81}$ There was a shift in the band position of the $\mathrm{Q}$ and $\mathrm{B}$ group stretching vibrations between PANI and $\mathrm{ND}_{x}$-g-PANI. The bands at around 1300 $\mathrm{cm}^{-1}$ and $1120 \mathrm{~cm}^{-1}$ in Fig. 4 are attributed to the $\mathrm{C}-\mathrm{N}$ stretching of the $\mathrm{B}$ group and in-plane bending vibration of the $\mathrm{C}-\mathrm{H}$ aromatic rings $(\mathrm{N}=\mathrm{Q}=\mathrm{N}, \mathrm{Q}=\mathrm{N}-\mathrm{B}$, and $\mathrm{Q}-\mathrm{NH}-\mathrm{B})$. The band at $830 \mathrm{~nm}$ is attributed to the $\mathrm{C}-\mathrm{H}$ out of plane bending of the 1-4, disubstituted ring structures (para-para coupling) and likely signifies the head to tail coupling of the monomeric structural units during aniline polymerization. The intensity ratio of $\mathrm{Q}$ to $\mathrm{B}$ is near unity for pristine PANI, suggesting the emeraldine salt-like form. However, the Q/B intensity ratio is shockingly low for $\mathrm{ND}_{x}-\mathrm{g}$-PANI, suggesting a low level doping. These results are in accordance with the XPS results (Table 2).

Table 2 Deconvolution of the XPS peaks and proportion of nitrogen chemical states

\begin{tabular}{llll}
\hline & \multicolumn{2}{c}{ Proportion $(\%)$ of nitrogen chemical states } \\
\cline { 2 - 4 } Electrode & $=\mathrm{N}$-(imine) & $-\mathrm{NH}$-(amine) & $\begin{array}{l}=\mathrm{N}^{+}(\text {protonated } \\
\text { amine) }\end{array}$ \\
\hline PANI & 0.335 & 0.182 & 0.481 \\
$\mathrm{ND}_{1}$ - -PANI & 0.158 & 0.808 & 0.033 \\
$\mathrm{ND}_{5}$ - $g$-PANI & 0.444 & 0.413 & 0.141 \\
$\mathrm{ND}_{10}-g$-PANI & 0.57 & 0.377 & 0.047
\end{tabular}

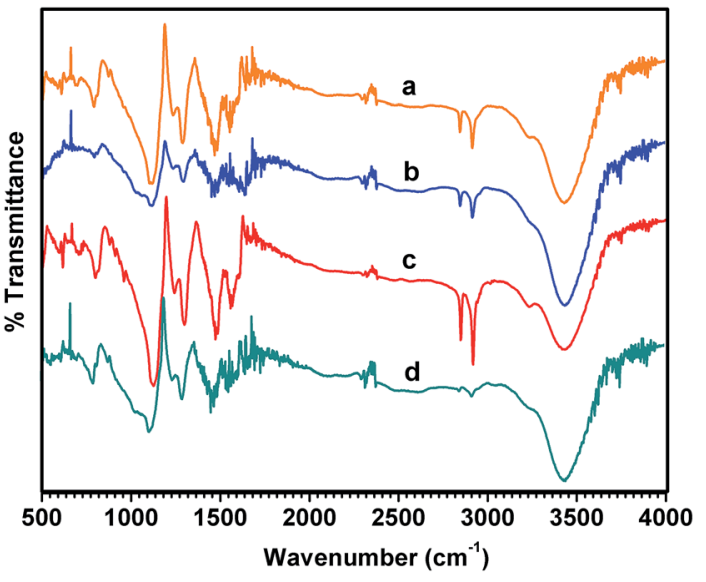

Fig. 4 Fourier transform infrared spectra of (a) $\mathrm{ND}_{1}-g$-PANI, (b) $\mathrm{ND}_{5}-$ g-PANI, (c) $\mathrm{ND}_{10}-g$-PANI, and (d) PANI.

\subsection{Thermogravimetric analysis}

The thermogravimetric curves of $\mathrm{ND}_{x}-g$-PANI and PANI are shown in Fig. $5 . \mathrm{ND}_{x}-g$-PANI and pristine PANI demonstrate a three-stage weight loss. The initial weight loss at around $100^{\circ} \mathrm{C}$ is mainly attributed to the elimination of residual water, and the second stage weight loss from $220{ }^{\circ} \mathrm{C}$ is due to the removal of dopant molecules. The third stage weight loss starting at around $380{ }^{\circ} \mathrm{C}$ is caused by the decomposition of the PANI chains. ${ }^{82}$ Table 3 shows the \%weight loss at each stage and the residual weight $(\%)$ at $600{ }^{\circ} \mathrm{C}$. The residual weight $\%$ at $600{ }^{\circ} \mathrm{C}$ increases with an increase in ND content in the composite, which is attributed to the fact that ND inclusion in $\mathrm{ND}_{x}-g$-PANI alters the thermal stability of the PANI backbone. ${ }^{83}$

\subsection{Amperometric determination of glucose by $\mathrm{ND}_{x}-g$-PANI}

The electrochemical properties and interfacial characteristics of $\mathrm{ND}_{1}-g$-PANI, $\mathrm{ND}_{5}-g$-PANI, $\mathrm{ND}_{10^{-}} g$-PANI, and pristine PANI were investigated using cyclic voltammetry and electrochemical impedance measurements, respectively, and the details are presented in the ESI SI-1 and $2 . \dagger$ As is known, the applied

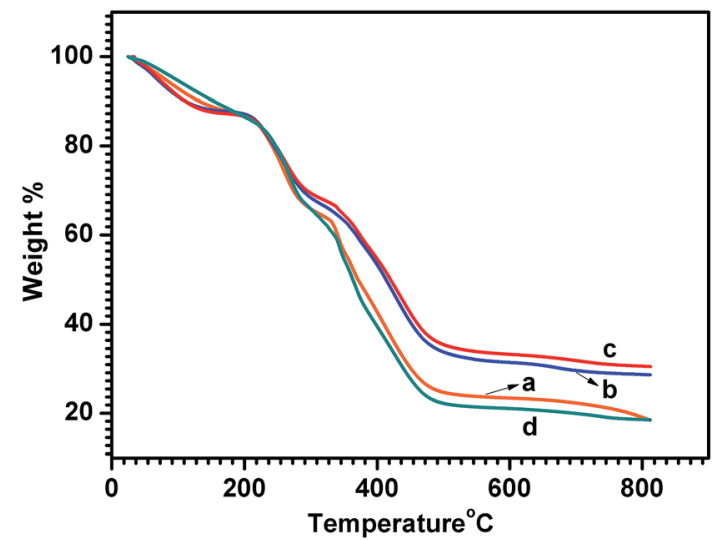

Fig. 5 TGA curves of (a) $N D_{1}-g-P A N I$, (b) $N D_{5}-g-P A N I$, (c) $N D_{10}-g-$ PANI, and (d) PANI. 
Table 3 Weight loss and residual weight (\%) of $\mathrm{ND}_{x}-g-\mathrm{PANI}$ and PANI

\begin{tabular}{|c|c|c|c|c|}
\hline \multirow[b]{2}{*}{ Samples } & \multicolumn{3}{|c|}{ Percentage (\%) weight losses } & \multirow{2}{*}{$\begin{array}{l}\text { Residual weigh } \\
(\%) \text { at } 600{ }^{\circ} \mathrm{C}\end{array}$} \\
\hline & Stage-I & Stage-II & Stage-III & \\
\hline PANI & 10.7 & 24.2 & 51.6 & 18.7 \\
\hline $\mathrm{ND}_{1}-g$-PANI & 11.6 & 22.4 & 43.2 & 22.7 \\
\hline $\mathrm{ND}_{5}-g$-PANI & 10.9 & 20.9 & 35.3 & 32.9 \\
\hline $\mathrm{ND}_{10^{-}} g$-PANI & 11.1 & 19.3 & 34.8 & 34.8 \\
\hline
\end{tabular}

potential has a definite influence on the sensing performances of an electrochemical sensor. To determine the optimum potential for amperometric glucose measurements, amperometric studies (Fig. SI- $3 \dagger$ ) were conducted by varying the applied potential between $+0.25 \mathrm{~V}$ and $+0.65 \mathrm{~V}$. Typically, the potential at the $\mathrm{ND}_{10^{-}}$ $g$-PANI/GOx-modified electrode was varied and the transduced current values were obtained for a $1 \mathrm{mM}$ glucose solution in $0.1 \mathrm{M}$ PBS. The glucose oxidation current was stable and maximum at $+0.40 \mathrm{~V}$ (Fig. SI- $3 \dagger$ ). Hence, the operating potential of $+0.40 \mathrm{~V}$ was chosen for further amperometric glucose measurements. Fig. 6a-d depict the amperometric responses upon the successive addition of glucose at the applied potential of $+0.40 \mathrm{~V}$ for the enzymatic glucose biosensors $\mathrm{ND}_{1}-g$-PANI/GOx, $\mathrm{ND}_{5}-g$-PANI/GOx, $\mathrm{ND}_{10}-g$-PANI/GOx, and pristine PANI/GOx, respectively. The $\mathrm{ND}_{10 x}-g$-PANI/GOx biosensor exhibits a much higher linear current response for glucose in the concentration range of 1-30 mM, with the correlation coefficient of 0.995 (Fig. 6, inset). This biosensor also exhibits a lower detection limit $(0.018 \mathrm{mM})$ than that reported for multilayer films of chitosan/ MWNT/GOx $(21 \mu \mathrm{M}) .{ }^{84}$ The sensitivity of the glucose sensor increases from $1.13 \mu \mathrm{A} \mathrm{mM}{ }^{-1}\left(\mathrm{ND}_{1}-g\right.$-PANI/GOx) to $1.49 \mu \mathrm{AmM}^{-1}$ ( $\mathrm{ND}_{5}-g$-PANI/GOx) and then to $2.03 \mu \mathrm{AmM}^{-1}$ ( $\mathrm{ND}_{10}-g$-PANI/GOx). The sensitivity of $\left(\mathrm{ND}_{10}-\mathrm{g}\right.$-PANI/GOx) is much higher than that of chitosan/MWNT/GOx $\left(0.45 \mu \mathrm{A} \mathrm{mM}^{-1}\right),{ }^{84}$ Nafion/GOx/CNTs (0.33 $\left.\mu \mathrm{A} \mathrm{mM}{ }^{-1}\right),{ }^{85}$ and GOx-Ru/CF microelectrode $\left(0.43 \mathrm{nA} \mathrm{mM}^{-1}\right){ }^{86}$ The increased sensitivity with ND clearly demonstrates its compatibility with GOx for the sensitive determination of glucose. Table 4 shows the comparison between the glucose biosensor performances and various other PANI-based biosensors reported in the literature. Table 4 reveals two striking pieces of information: (i) the biosensor based on $\mathrm{ND}_{10}$ - $g$-PANI $\mathrm{NF}$ exhibits much-improved sensitivity $\left(2.03 \mu \mathrm{A} \mathrm{mM}^{-1}\right)$, wider linear concentration range (1-30 mM), and lower detection limit (0.018 $\mathrm{mM}$ ) and (ii) the $\mathrm{ND}_{10}-g$-PANI NF-based glucose sensor shows superior sensor performances than many PANI and carbon nanostructure (e.g. MWNT)-based biosensors (Table 4).

\subsection{Interferences}

In the present study, an applied potential of $+0.40 \mathrm{~V}$ was used to monitor the glucose concentration. Other electroactive species such as ascorbic acid (AA), dopamine (DA), and acetaminophen (AP) present in the sensing solution had higher electron transfer rates than glucose. As a result, the transduced net current would
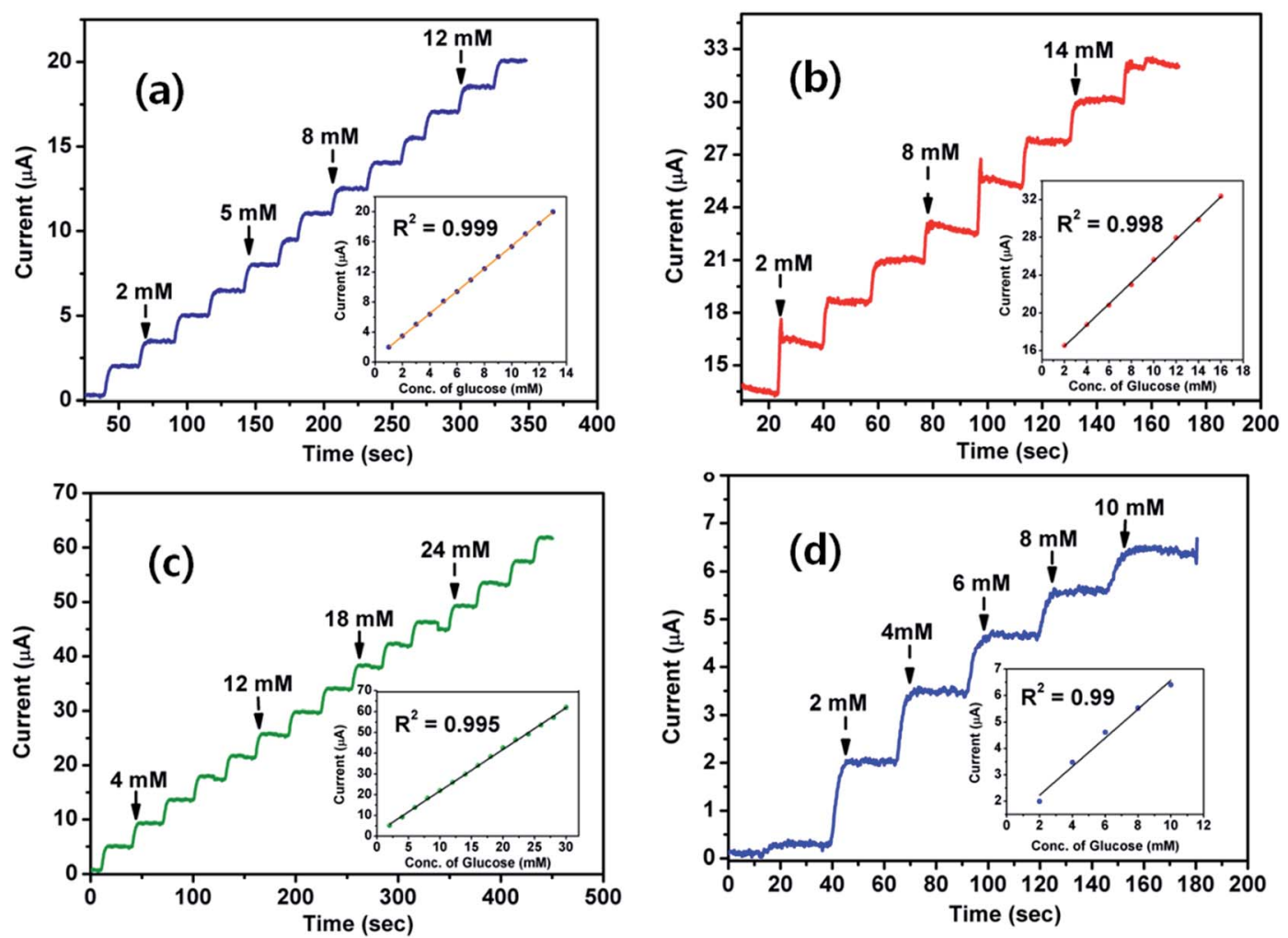

Fig. 6 Amperometric current responses of the (a) ND ${ }_{1}-g$-PANI/GOx, (b) ND $5-g-P A N I / G O x$, (c) ND $10-g$-PANI/GOx, and (d) PANI/GOx biosensors at $+400 \mathrm{mV}$ in $0.1 \mathrm{M}$ PBS ( $\mathrm{pH}$ 7.0). Inset: the calibration curve. 
Table 4 Comparison of glucose biosensor performances

\begin{tabular}{|c|c|c|c|c|}
\hline Material & Detection limit & Linear range & Sensitivity & Ref. \\
\hline PANI/GOx & $0.062 \mathrm{mM}$ & $1-10 \mathrm{mM}$ & $0.54 \mu \mathrm{A} \mathrm{mM} M^{-1}$ & This work \\
\hline $\mathrm{ND}_{1}-g$-PANI/GOx & $0.035 \mathrm{mM}$ & $1-13 \mathrm{mM}$ & $1.13 \mu \mathrm{A} \mathrm{mM} M^{-1}$ & This work \\
\hline $\mathrm{ND}_{5}-g$-PANI/GOx & $0.02 \mathrm{mM}$ & $1-16 \mathrm{mM}$ & $1.49 \mu \mathrm{A} \mathrm{mM}^{-1}$ & This work \\
\hline $\mathrm{ND}_{10^{-}}-g-\mathrm{PANI} / \mathrm{GOx}$ & $0.018 \mathrm{mM}$ & $1-30 \mathrm{mM}$ & $2.03 \mu \mathrm{A} \mathrm{mM} M^{-1}$ & This work \\
\hline NiHCF/PANI/graphene & $0.5 \mu \mathrm{M}$ & $0.001-0.765 \mathrm{mM}$ & $487.33 \mu \mathrm{A} \mathrm{mM}{ }^{-1} \mathrm{~cm}^{-2}$ & 88 \\
\hline AuNPs/PANI-NF/GOx & $0.5 \mu \mathrm{M}$ & $0.5-16 \mathrm{mM}$ & - & 89 \\
\hline PANI/PANAA-GOx & $1 \mu \mathrm{M}$ & $0.005-5 \mathrm{mM}$ & $16 \mathrm{~mA} \mathrm{M}^{-1} \mathrm{~cm}^{-2}$ & 90 \\
\hline PANI/MWCNTs & $0.02 \mathrm{mM}$ & $0.5-12 \mathrm{mM}$ & $0.94 \mu \mathrm{A} \mathrm{mM}^{-1}$ & 91 \\
\hline Nafion-silica/MWCNTs- $g$-PANI/GOx & $0.1 \mu \mathrm{M}$ & $1-10 \mathrm{mM}$ & $5.01 \mu \mathrm{A} \mathrm{mM} M^{-1}$ & 25 \\
\hline BNNTs-PANI-Pt & $0.18 \mu \mathrm{M}$ & $0.01-8 \mathrm{mM}$ & $19.02 \mathrm{~mA} \mathrm{M}^{-1} \mathrm{~cm}^{-2}$ & 92 \\
\hline PANI/gold nanorod/GOx & $5.8 \mu \mathrm{M}$ & $17.6 \mu \mathrm{M}^{-1} \mathrm{mM}$ & $13.8 \mu \mathrm{A} \mathrm{mM}{ }^{-1} \mathrm{~cm}^{-2}$ & 93 \\
\hline $\mathrm{PANI} / \mathrm{PB}$ & $0.4 \mu \mathrm{M}$ & $2-1600 \mu \mathrm{M}$ & $99.4 \mu \mathrm{A} \mathrm{mM}{ }^{-1} \mathrm{~cm}^{-2}$ & 94 \\
\hline Cyt c/Au NPs/PANI-NS & $0.01 \mathrm{mM}$ & $0.01-3.2 \mathrm{mM}$ & $63.1 \mu \mathrm{A} \mathrm{mM}{ }^{-1} \mathrm{~cm}^{-2}$ & 95 \\
\hline Pt NPs/PANI hydrogel heterostructure & $0.7 \mu \mathrm{M}$ & $0.01-8 \mathrm{mM}$ & $96.1 \mu \mathrm{A} \mathrm{mM}{ }^{-1} \mathrm{~cm}^{-2}$ & 96 \\
\hline GOx-PANI-PecNPs & $43.5 \mu \mathrm{M}$ & $0.06-4 \mathrm{mM}$ & $79.49 \mu \mathrm{A} \mathrm{mM} M^{-1} \mathrm{~cm}^{-2}$ & 97 \\
\hline GOx-graphene/PANI/Au NPs/GCE & $0.6 \mu \mathrm{M}$ & $4.0 \mu \mathrm{M}-1.12 \mathrm{mM}$ & - & 98 \\
\hline $\mathrm{GOx} / n-\mathrm{TiO}_{2} / \mathrm{PANI} / \mathrm{GCE}$ & $18 \mu \mathrm{M}$ & $0.02-6.0 \mathrm{mM}$ & $6.31 \mu \mathrm{A} \mathrm{mM} M^{-1} \mathrm{~cm}^{-2}$ & 99 \\
\hline
\end{tabular}

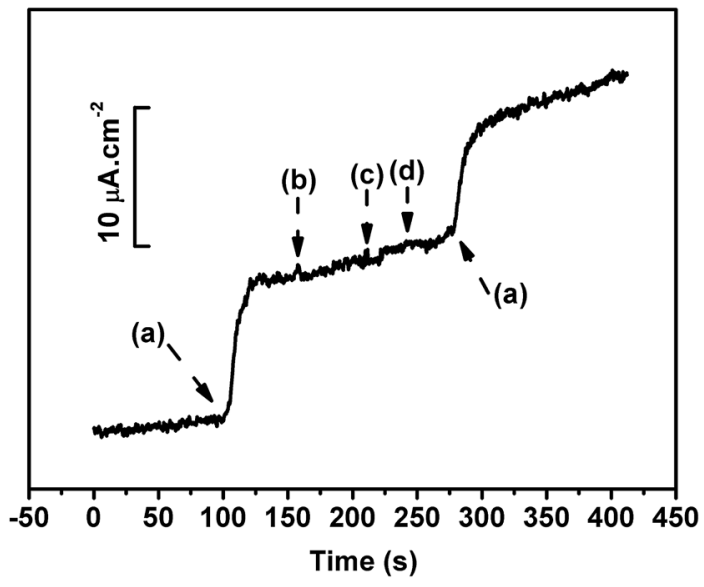

Fig. 7 Effect of interfering signals of glucose $(5 \mathrm{mM})(\mathrm{a})$, ascorbic acid $(2 \mathrm{mM})(\mathrm{b})$, dopamine (2 $\mathrm{mM})(\mathrm{c})$, and acetaminophen $(2 \mathrm{mM})(\mathrm{d})$ at $\mathrm{ND}_{10}-g-\mathrm{PANI} / \mathrm{GOx}$.

contain an interference signal. Thus, the concentration of glucose would be overestimated. Hence, it was essential to eliminate the current contributions from interfering substances. Nafion, which has ion-exchange capabilities, can minimize the interferences caused by these electroactive species. ${ }^{87}$ Fig. 7 represents the amperometric response of the $\mathrm{ND}_{10}-\mathrm{g}$-PANI/GOx biosensor for $5 \mathrm{mM}$ of glucose (a) with ascorbic acid ( $2 \mathrm{mM})(\mathrm{b})$, dopamine (2 $\mathrm{mM}$ ) (c), and acetaminophen (2 mM) (d). It can be seen from Fig. 7 that the spiking interference solution did not alter the current response of the $\mathrm{ND}_{10^{-}} g$-PANI/GOx biosensor. Thus, the $\mathrm{ND}_{10^{-}} g$ PANI/GOx biosensor exhibits high selectivity towards sensing glucose.

\subsection{Real sample analysis}

The reliability and practical use of $\mathrm{ND}_{10}-g$-PANI/GOx were tested by estimating the glucose concentration in a human serum sample and comparing the value with a commercial glucose
Table 5 Real sample analysis

\begin{tabular}{lllll}
\hline $\begin{array}{l}\text { Sample (serum } \\
\text { +added } \\
[\mathrm{Glu}])\end{array}$ & $\begin{array}{l}\text { Reference } \\
\text { values }^{a}(\mathrm{mM})\end{array}$ & $\begin{array}{l}\text { Found } \\
\text { values }^{b}(\mathrm{mM})\end{array}$ & $\begin{array}{l}\mathrm{RSD}^{c} \\
(\%)\end{array}$ & $\begin{array}{l}\text { Recovery } \\
(\%)\end{array}$ \\
\hline $\begin{array}{l}\text { Serum + } 0 \mathrm{mM} \\
\text { Serum + 1 mM }\end{array}$ & 4.44 & 4.44 & 2.81 & 100 \\
Serum + 5 mM & 9.43 & 5.38 & 4.02 & 99.07 \\
Serum + 8 mM & 12.36 & 9.43 & 2.35 & 100.21 \\
& & 12.15 & 3.57 & 98.3
\end{tabular}

${ }^{a}$ Determined using a commercial glucose meter (CareCens ${ }^{\mathrm{TM}} \mathrm{N}$, GM5051A, i-SENS, Inc., Korea). ${ }^{b}$ Determined using the $\mathrm{ND}_{10^{-}} g$-PANI/ GOx biosensor. ${ }^{c}$ Number of measurements $=3$.

meter (CareCens ${ }^{\mathrm{TM}} \mathrm{N}$, GM5051A, i-SENS, Inc., Korea). Table 5 presents the glucose levels separately determined using the fabricated $\mathrm{ND}_{10^{-}} g$-PANI/GOx sensor and glucose meter. The glucose levels obtained at $\mathrm{ND}_{10}-\mathrm{g}$-PANI/GOx agree well with the glucose values observed from the glucose meter. The recovery values for the added glucose concentrations were between 98.3 and $100.21 \%$. With the root mean square deviation (R.S.D) value of $\sim 3.0 \%(n=3)$ for the recovery, $\mathrm{ND}_{10}$ - $g$-PANI/GOx was proven to be useful for the detection of glucose in human serum samples.

\subsection{Reproducibility, repeatability, and stability}

The reproducibility, repeatability, and lifetime (stability) of the fabricated sensor were evaluated and the details are presented in SI-3. $\dagger$ The results revealed that the sensor has satisfactory reproducibility $(\mathrm{RSD}=1.2 \%, n=6)$, repeatability $(\mathrm{RSD}=$ $1.42 \%, n=4$ ), and good stability for 30 days (retaining $97 \%$ of its original current responses).

\section{Conclusions}

Nanoflowers (NF) of PANI chains were grafted onto the surface of nanodiamonds (ND) by optimizing the binding sites on the 
ND surface to augment secondary nucleation for PANI chains. The NF of PANI on ND caused the effective immobilization of glucose oxidase (the enzyme) and resulted in high performances (wide concentration range and low detection limit) for glucose detection. Our studies demonstrated a simple flowerlike modification strategy on the surface of ND and also opened-up further avenues for the development of efficient biosensing platforms for other target molecules.

\section{Acknowledgements}

This work was supported by the Priority Research Centers Program through a National Research Foundation of Korea (NRF) grant funded by the Ministry of Education, Science and Technology (2009-0093819) and a funded research project (NRF2014R1A1A4A03004026). The authors gratefully acknowledge Dr. Miklos Verios, Institute for Solid State Physics and Optics, Higher Research Center for Physics, Hungarian Academy of Science, Hungary, for providing the ND sample.

\section{References}

1 S. Arimori, C. J. Ward and T. D. James, Tetrahedron Lett., 2002, 43, 303-305.

2 H. Cao, D. I. Diaz, N. Dicesare, J. R Lakowicz and M. D. Heagy, Org. Lett., 2002, 4, 1503-1505.

3 O. Schaetzle, F. Barrière and U. Schröder, Energy Environ. Sci., 2009, 2, 96-99.

4 E. Simon, C. M. Halliwell, C. S. Toh, A. E. Cass and P. N. Bartlett, Bioelectrochemistry, 2002, 55, 13-15.

5 N. L. Akers, C. M. Moore and S. D. Minteer, Electrochim. Acta, 2005, 50, 2521-2525.

6 Z. Wen, B. Ye and X. Zhou, Bioelectrochemistry, 1997, 9, 641.

7 S. Calabrese Barton, J. Gallaway and P. Atanassov, Chem. Rev., 2004, 104, 4867.

8 S. Komathi, N. Muthuchamy, K. P. Lee and A. I. Gopalan, Biosens. Bioelectron., 2016, 84, 64-71.

9 T. Kuwahara, T. Homma, M. Kondo and M. Shimomura, Synth. Met., 2009, 159, 1859-1864.

10 X. B. Yan, X. J. Chen, B. K. Tay and K. A. Khor, Electrochem. Commun., 2007, 9, 1269-1275.

11 L. Xu, Y. Zhu, L. Tang, X. Yang and C. Li, Electroanalysis, 2007, 19, 717-722.

12 M. Zhao, X. Wu and C. Cai, J. Phys. Chem. C, 2009, 113, 49874996.

13 J. Lu, I. Do, L. T. Drzal, R. M. Worden and I. Lee, ACS Nano, 2008, 2, 1825-1832.

14 J. Y. Chiu, C. M. Yu, M. J. Yen and L. C. Chen, Biosens. Bioelectron., 2009, 24, 2015.

15 M. Yuan, N. Konstantopoulos, J. Lee, L. Hansen, Z. W. Li, M. Karin and S. E. Shoelson, Science, 2001, 293, 1673-1677.

16 H. Liu, J. Kameoka, D. A. Czaplewski and H. G. Craighead, Nano Lett., 2004, 4, 671-675.

17 Z. Wang, S. Liu, P. Wu and C. Cai, Anal. Chem., 2009, 81, 1638-1645.

18 A. I. Gopalan, N. Muthuchamy, S. Komathi and K. P. Lee, Biosens. Bioelectron., 2016, 84, 53-63.
19 N. Muthuchamy, K. P. Lee and A. I. Gopalan, Biosens. Bioelectron., 2017, 89, 390-399.

20 M. Ding, Y. Tang, P. Gou, M. J. Reber and A. Star, Adv. Mater., 2011, 23, 536-540.

21 Y. Zhang, X. Yang and Z. Gao, RSC Adv., 2015, 5, 21675.

22 P. Santhosh, K. M. Manesh, A. Gopalan and K. P. Lee, Sens. Actuators, B, 2007, 125, 92-99.

23 P. Santhosh, A. Gopalan and K. P. Lee, J. Catal., 2006, 238, 177-185.

24 P. Santhosh, K. M. Manesh, A. Gopalan and K. P. Lee, Anal. Chim. Acta, 2006, 575, 32-38.

25 A. I. Gopalan, K. P. Lee, D. Ragupathy, S. H. Lee and J. W. Lee, Biomaterials, 2009, 30, 5999-6005.

26 L. F. Li, D. Totir, B. Miller, G. Chottiner, A. Argoitia, J. C. Angus and D. Scherson, J. Am. Chem. Soc., 1997, 119, 7875-7876.

27 N. Vinokur, B. Miller, Y. Avyigal and R. Kalish, J. Electrochem. Soc., 1996, 143, L238.

28 D. R. Dunphy, S. B. Mendes, S. S. Saavedra and N. R. Armstrong, Anal. Chem., 1997, 71, 3086.

29 T. Yano, E. Popa, D. A. Tryk, K. Hashimoto and A. Fujishima, J. Electrochem. Soc., 1999, 146, 1081.

30 J. Xu, Q. Chen and G. M. Swain, Anal. Chem., 1998, 70, 31463154.

31 Q. Chen, M. C. Granger, T. E. Lister and G. M. Swain, J. Electrochem. Soc., 1997, 144, 3086.

32 C. C. Fu, H. Y. Lee, K. Chen, T. S. Lim, H. Y. Wu, P. K. Lin, P. K. Wei, P. H. Tsao, H. C. Chang and W. Fann, Proc. Natl. Acad. Sci. U. S. A., 2007, 104, 727-732.

33 R. Lam, M. Chen, E. Pierstorff, H. Huang, E. Osawa and D. Ho, ACS Nano, 2008, 10, 2095-2102.

34 J. Wang, G. Chen, M. P. Chatrathi, A. Fujishima, D. A. Tryk and D. Shin, Anal. Chem., 2003, 75, 935-939.

35 Q. Chen, D. M. Gruen, A. R. Krauss, T. D. Corrigan, M. Witek and G. M. Swain, J. Electrochem. Soc., 2001, 148, E44-E51.

36 A. Härtl, E. Schmich, J. A. Garrido, J. Hernando, S. C. Catharino, S. Walter, P. Feulner, A. Kromka, D. Steinmüller and M. Stutzmann, Nat. Mater., 2004, 3, 736-742.

37 W. Zhao, J. J. Xu, Q. Q. Qiu and H. Y. Chen, Biosens. Bioelectron., 2006, 22, 649-655.

38 J. T. Zhu, C. G. Shi, J. J. Xu and H. Y. Chen, Bioelectrochemistry, 2007, 71, 243-248.

39 T. S. Huang, Y. Tzeng, Y. K. Liu, Y. C. Chen, K. R. Walker, R. Guntupalli and C. Liu, Diamond Relat. Mater., 2004, 13, 1098-1102.

40 L. Li, J. L. Davidson and C. M. Lukehart, Carbon, 2006, 44, 2308.

41 X. Q. Zhang, M. Chen, R. Lam, X. Xu, E. Osawa and D. Ho, ACS Nano, 2009, 3, 2609-2616.

42 P. Actis, M. Manesse, C. Nunes-Kirchner, G. Wittstock, Y. Coffinier, R. Boukherroub and S. Szunerits, Phys. Chem. Chem. Phys., 2006, 8, 4924-4931.

43 X. Y. Zhao, J. B. Zang, Y. H. Wang, L. Y. Bian and J. K. Yu, Electrochem. Commun., 2009, 11, 1297-1300.

44 L. Li, Y. Wang, L. Pan, Y. Shi, W. Cheng, Y. Shi and G. Yu, Nano Lett., 2015, 15, 1146-1151. 
45 P. Santhosh, K. M. Manesh, S. Uthayakumar, A. I. Gopalan and K. P. Lee, Biosens. Bioelectron., 2009, 24, 2008-2009.

46 A. V. Karmenyan, E. Perevedentseva, M. Veres and C. L. Cheng, Plasmonics, 2013, 8, 325-333.

47 P. Csikvari, A. Somogyi, M. Veres, G. Hárs and A. Tóth, Diamond Relat. Mater., 2009, 18, 1459-1465.

48 A. I. Gopalan, K. P. Lee and S. Komathi, Biosens. Bioelectron., 2010, 26, 1638-1643.

49 A. I. Gopalan, S. Komathi, G. S. Anand and K. P. Lee, Biosens. Bioelectron., 2013, 46, 136-141.

50 T. J. Ohara, R. Rajagopalan and A. Heller, Anal. Chem., 1994, 66, 2451.

51 D. Zhou, Y. Li, J. Wang, P. Xu and X. Han, Mater. Lett., 2011, 65, 3601-3604.

52 C. Zhou, J. Han and R. Guo, Macromolecules, 2008, 41, 64736479.

53 S. Sadasivan, D. Khushalani and S. Mann, Chem. Mater., 2005, 17, 2765-2770.

54 G. Sai-Anand, A. I. Gopalan, S. W. Kang and K. P. Lee, IEEE Electron Device Lett., 2013, 34, 1065-1067.

55 W. Chen, R. B. Rakhi and H. N. Alshareef, J. Phys. Chem. C, 2013, 117, 15009-15019.

56 M. Hosseini, M. M. Momeni and M. Faraji, J. Mater. Sci., 2010, 45, 2365.

57 I. Kovalenko, D. G. Bucknall and G. Yushin, Adv. Funct. Mater., 2010, 20, 3979.

58 A. D. Carswell, E. A. O'Rea and B. P. Grady, J. Am. Chem. Soc., 2003, 125, 14793-14800.

59 H. Mao, X. Lu, D. Chao, L. Cui and W. Zhang, Mater. Lett., 2008, 62, 998-1001.

60 L. S. Jan and M. A. Siddig, Chinese J. Poly. Scien., 2011, 29, 181-190.

61 T. Wang, W. Zhong, X. Ning, Y. Wang and W. Yang, J. Colloid Interface Sci., 2009, 334, 108-112.

62 Q. Xu and X. Zhao, J. Mater. Chem., 2012, 22, 16416-16421.

63 X. Zhang, S. Wang, M. Liu, J. Hui, B. Yang, L. Tao and Y. Wei, Toxicol. Res., 2013, 2, 335-342.

64 W. Yin and E. Ruckenstein, Synth. Met., 2000, 108, 39-46.

65 P. Jiménez, P. Castell, R. Sainz, A. Ansón, M. Martínez, A. Benito and W. K. Maser, J. Phys. Chem. B, 2010, 114, 1579-1585.

66 J. De Albuquerque, L. Mattoso, R. Faria, J. Masters and A. MacDiarmid, Synth. Metal, 2004, 146, 1-10.

67 S. Dutt and P. Siril, Mater. Lett., 2014, 124, 50-53.

68 X. Zhu, K. Hou, C. Chen, W. Zhang, H. Sun, G. Zhang and

Z. Gao, High Perform. Polym., 2015, 27, 207-216.

69 T. Hashimoto, R. Iwase, A. Murakami and T. Yamaoka, Polym. Degrad. Stab., 2009, 94, 1349-1353.

70 V. Chaudhary and A. Kaur, RSC Adv., 2016, 6, 95349-95357.

71 S. Palaniappan and V. Nivasu, New J. Chem., 2002, 26, 14901494.
72 S. Shreepathi and R. Holze, Chem. Mater., 2005, 17, 40784085.

73 S. Virji, J. Huang, R. B. Kaner and B. H. Weiller, Nano Lett., 2004, 4, 491-496.

74 J. Jang, J. Ha and J. Cho, Adv. Mater., 2007, 19, 1772-1775.

75 S. Cho, O. S. Kwon, S. A. You and J. Jang, J. Mater. Chem. A, 2013, 1, 5679-5688.

76 F. J. Liu, L. M. Huang, T. C. Wen, C. F. Li, S. L. Huang and A. Gopalan, Synth. Met., 2008, 158, 767.

77 F. J. Liu, L. M. Huang, T. C. Wen and A. Gopalan, Synth. Met., 2007, 157, 651.

78 E. T. Kang, K. G. Neoh, S. H. Khor, K. L. Tan and B. T. G. Tan, Polymer, 1990, 31, 202-207.

79 A. Dey, S. De, A. De and S. K. De, Nanotech., 2004, 15, 1277.

80 V. Rajendran, A. Gopalan, T. Vasudevan and T. C. Wen, J. Electrochem. Soc., 2000, 147, 3014-3020.

81 L. Zhang, Z. D. Zujovic, H. Peng, G. A. Bowmaker, P. A. Kilmartin and J. Travas-Sejdic, Macromolecules, 2008, 41, 8877-8884.

82 D. Lee and K. Char, Polym. Degrad. Stab., 2002, 75, 555-560. 83 Y. He, Q. Cheng, V. Pavlinek, C. Li and P. Saha, Inter. J. Poly. Anal. Ch., 2008, 13, 25.

84 B. Y. Wu, S. H. Hou, M. Yu, X. Qin, S. Li and Q. Chen, Mater Sci Eng C Mater Biol Appl., 2009, 29, 346.

85 Y. C. Tsai, S. C. Li and J. M. Chen, Langmuir, 2005, 21, 3653. 86 T. Kohma, D. Oyamatsu and S. Kuwabata, Electrochem. Commun., 2007, 9, 1012.

87 K. M. Manesh, H. T. Kim, P. Santhosh, A. I. Gopalan and K. P. Lee, Biosens. Bioelectron., 2008, 23, 771.

88 Y. Kong, Y. Sha, Y. Tao, Y. Qin, H. Xue and M. Lu, J. Electrochem. Soc., 2014, 161, B269-B274.

89 Y. Xian, Y. Hu, F. Liu, Y. Xian, H. Wang and L. Jin, Biosens. Bioelectron., 2006, 21, 1996-2000.

90 D. Shan, S. Wang, Y. He and H. Xue, Mater. Sci. Eng. C., 2008, 28, 213-217.

91 Q. Sheng and J. Zheng, Biosens. Bioelectron., 2009, 24, 16211628.

92 J. Wu and L. Yin, ACS Appl. Mater. Interfaces, 2011, 3, 43544362 .

93 U. Tamer, A. I. Seçkin, E. Temur and H. Torul, Int. J. Electrochem., 2011, 2011, 869742.

94 X. Chen, Z. Chen, R. Tian, W. Yan and C. Yao, Anal. Chim. Acta, 2012, 723, 94-100.

95 C. Xiang, Y. Zou, S. Qiu, L. Sun, F. Xu and H. Zhou, Talanta, 2013, 110, 96-100.

96 D. Zhai, B. Liu, Y. Shi, L. Pan, Y. Wang, W. Li, R. Zhang and G. Yu, ACS Nano, 2013, 7, 3540-3546.

97 B. Thakur, C. A. Amarnath and S. N. Sawant, RSC Adv., 2014, 4, 40917-40923.

98 Q. Xu, S. X. Gu, L. Jin, Y. E. Zhou, Z. Yang, W. Wang and X. Hu, Sens Actuators B, 2014, 190, 562-569.

99 W. Tang, L. Li and X. Zeng, Talanta, 2015, 131, 417-423. 